DR-3

\title{
AN ECO-FRIENDLY STEREOSELECTIVE SYNTHESIS OF NOVEL DERIVATIVES OF INDENO[1,2-b]PYRROLE AND INDENO[1,2-c]PYRIDAZINE
}

\author{
N. V. Nosova, ${ }^{1}$ A. N. Yankin, ${ }^{2}$ K. D. II ina, ${ }^{1}$ L. F. Gein, ${ }^{3}$ V. L. Gein, ${ }^{1}$ M. V. Dmitriev ${ }^{4}$
}

${ }^{1}$ Perm State Pharmaceutical Academy, Polevaya St. 2, 614990, Perm, Russian Federation

${ }^{2}$ St. Petersburg State University, Universitetskaya Nab. 7/9, 199034, St. Petersburg, Russian Federation

${ }^{3}$ Perm State Medical University, Petropavlovskiy St. 26, 614990, Perm, Russian Federation ${ }^{4}$ Perm State National Research University, Bukirev St. 15, 614990, Perm, Russian Federation

E-mail: natalia.v.nosova@mail.ru

Abstract. It is known that ninhydrin has been utilized in many heterocyclic preparations [1]. We developed a simple and effective, straightforward, stereoselective synthesis of functionalized indenopyrroles $\mathbf{4 a - g}$ with a good yield from the reaction of ninhydrin $\mathbf{1}$ and acetoacetic acid amides $\mathbf{2}$ in ethanol at room temperature. This method is cost-effective, environmentally and experimentally safe, easy to handle, clean and efficient.<smiles>O=c1c(=O)c2ccccc2c1=O</smiles>

1

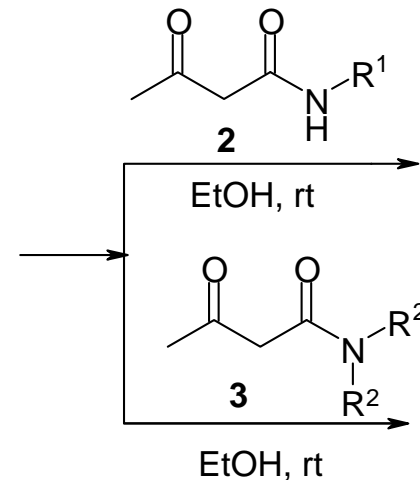

$\mathrm{EtOH}, \mathrm{rt}$<smiles>[R7]N1C(=O)/C(=C(/C)O)C2(O)C(=O)c3ccccc3C12O</smiles>

4a-g<smiles>[R6]N([R2])C(=O)C(C(C)=O)C1(O)C(=O)c2ccccc2C1=O</smiles>

$\mathrm{R}^{1}=\mathrm{Ph}(4 \mathrm{a}, 8 \mathrm{a}) ; 4-\mathrm{CH}_{3} \mathrm{C}_{6} \mathrm{H}_{4}(4 \mathrm{~b}, 8 \mathrm{~b}) ; 2,4-\left(\mathrm{CH}_{3}\right)_{2} \mathrm{C}_{6} \mathrm{H}_{3}(4 \mathrm{c}, 8 \mathrm{c}) ; 2-\mathrm{CH}_{3} \mathrm{OC}_{6} \mathrm{H}_{4}(4 \mathrm{~d}, 8 \mathrm{~d}) ; 4-$ $\mathrm{ClC}_{6} \mathrm{H}_{4}(4 \mathrm{e}, 8 \mathrm{e}) ; 2-\mathrm{ClC}_{6} \mathrm{H}_{4}$ (4f, 8f); $\mathrm{H}(4 \mathrm{~g}, 8 \mathrm{~g}) ; \mathrm{R}^{2}=\mathrm{Me}(6 \mathrm{a}) ; \mathrm{Et}(6 \mathrm{~b})$

The interaction of ninhydrin $\mathbf{1}$ with $N, N$-dialkylacetoacetamides $\mathbf{3}$ as the methylene components under the same conditions led to the novel $N, N$-dialkyl-3-oxobutanamides $\mathbf{6 a , b}$.

Further we carried out the reaction of the indeno[1,2-b]pyrrole derivatives $\mathbf{4 a - g}$ with hydrazine 7 in ethanol. The results of this study showed that the interaction of compounds $\mathbf{4}$ and $\mathbf{7}$ led to the formation of novel indeno[1,2-c]pyridazine derivatives 8a-g.<smiles>[R]N1C(=O)/C(=C(/C)O)C2(O)C(=O)c3ccccc3C12O</smiles>

$4 a-g$

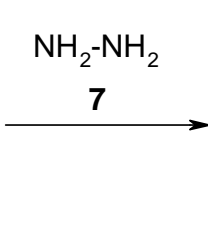<smiles>[R7]NC(=O)c1c(C)nnc2c1C(=O)c1ccccc1-2</smiles>

$8 \mathrm{a}-\mathrm{g}$

All the products were characterized by IR, ${ }^{1} \mathrm{H}$ NMR, ${ }^{13} \mathrm{C}$ NMR, and mass spectroscopic studies. The structures of compounds $\mathbf{4 g}, \mathbf{4 h}, \mathbf{6 b}$ and $\mathbf{8 b}$ were confirmed by single crystal X-ray analysis.

\section{References}

1. Hansen D. B. The development of novel ninhydrin analoges / D. B. Hansen, M.M. Joullie // Chem. Soc. Rev. -2005. -Vol. 34. -P. 408-417. 